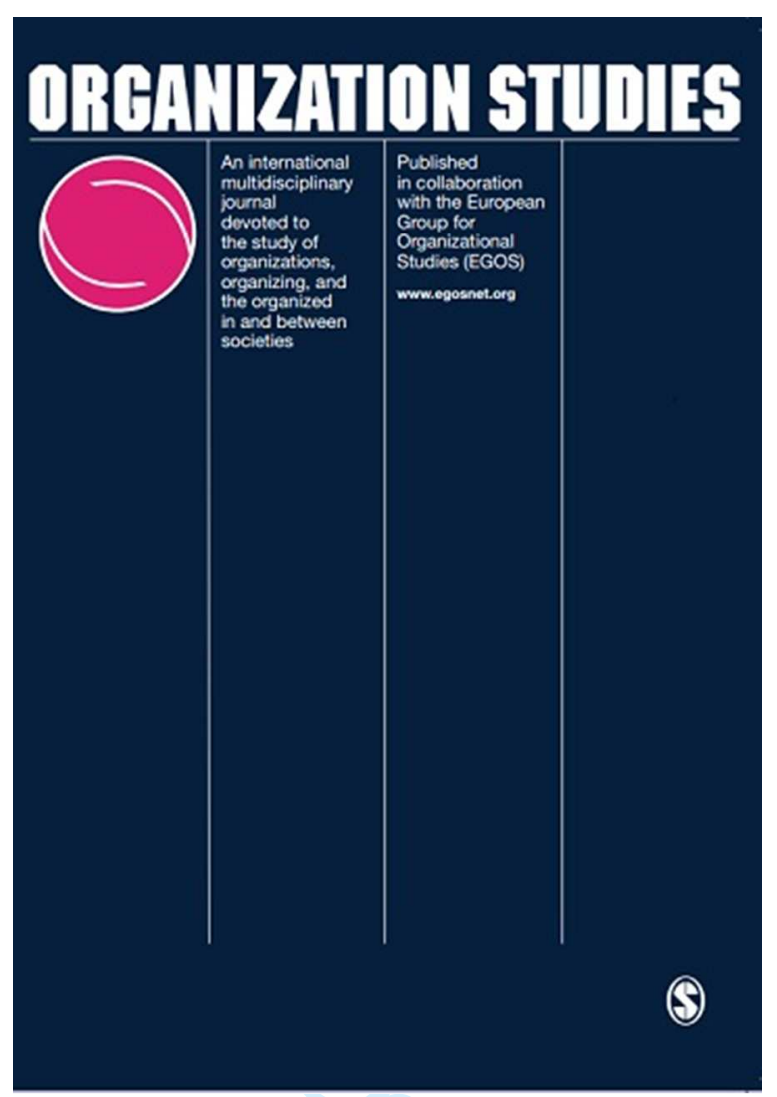

\title{
Performing Values Practices and Grassroots Organizing: The Case of Solidarity Economy Initiatives in Greece
}

\begin{tabular}{|r|l|}
\hline Journal: & Organization Studies \\
\hline Manuscript ID & OS-17-0190.R2 \\
\hline Manuscript Type: & Article \\
\hline Keywords: & $\begin{array}{l}\text { Alternative organizational forms, Grassroots Exchange Networks, Solidarity } \\
\text { economy, Values practices, Performance, Judith Butler, Gibson-Graham }\end{array}$ \\
\hline Abstract: & $\begin{array}{l}\text { This article discusses solidarity economy initiatives as instances of } \\
\text { grassroots organizing, and explores how 'values practices' are performed } \\
\text { collectively during times of crisis. In focusing on how power, discourse and } \\
\text { subjectivities are negotiated in the everyday practices of grassroots } \\
\text { exchange networks (GENs) in crisis-stricken Greece, the study unveils and } \\
\text { discusses three performances of values practices, namely mobilization of } \\
\text { values, re-articulation of social relations, and sustainable living. Based on } \\
\text { these findings, and informed by theoretical analyses of performativity, we } \\
\text { propose a framework for studying the production and reproduction of } \\
\text { values in the context of GENs, and the role of values in organizing } \\
\text { alternatives. }\end{array}$ \\
\hline
\end{tabular}


1

2

3

4

5

6

7

8

9

10

11

12

13

14

15

16

17

18

19

20

21

22

23

24

25

$2 \varepsilon$

29

30

31

32

33

34

35

36

39

40

41

42

43

44

45

46

47

48

49

50

51

52

53

54

55

56

57

58

59

60

\section{5} (a)

1

SCHOLARONE"

Manuscripts

7

(

2

.

36
8 (1) . 45 48 (5) 5 


\title{
Performing Values Practices and Grassroots Organizing: The Case of Solidarity Economy Initiatives in Greece
}

\begin{abstract}
This article discusses solidarity economy initiatives as instances of grassroots organizing, and explores how 'values practices' are performed collectively during times of crisis. In focusing on how power, discourse and subjectivities are negotiated in the everyday practices of grassroots exchange networks (GENs) in crisis-stricken Greece, the study unveils and discusses three performances of values practices, namely mobilization of values, rearticulation of social relations, and sustainable living. Based on these findings, and informed by theoretical analyses of performativity, we propose a framework for studying the production and reproduction of values in the context of GENs, and the role of values in organizing alternatives.
\end{abstract}

\section{Keywords}

grassroots exchange network (GEN), Greece, financial crisis, values practices, performance, Judith Butler, Gibson-Graham

\section{Introduction}

Recent empirical research on the impact of the 2008 global financial crisis (GFC) on grassroots organizations has unveiled the importance of studying how people collectively enact shared values (Chen, Lune, \& Queen, 2013). However, there remains 'considerable ambiguity in the role values play' (Martin \& Upham, 2016, p. 205), particularly in relation to how they affect the pursuit of alternative organizational forms (see, for example, Dinerstein, 2007; Amin, 2009; O’Reilly, Lain, Sheehan, Smale, \& Stuart, 2011; De Bakker, Den Hond, King, \& Weber, 2013; Cheney, Cruz, Peredo, \& Nazareno, 2014). Recent research, emerging mainly from crisis-stricken Greece, acknowledges that groups persistently form initiatives to reject conventional bureaucratic practices, resist extreme neoliberal capitalist reforms and 
strive for social transformation (Daskalaki \& Kokkinidis, 2017; Daskalaki, 2017; Arampatzi, 2016; Karyotis \& Kioupokiolis, 2015; Chatzidakis, 2013; Petropoulou, 2013). Yet few studies explore in depth how value systems and/or their re-production may drive and sustain such alternatives.

Inspired by an investigation of values practices in the development of an honour code in a large business school (see Gehman, Treviño, \& Garud, 2013), our proposed framework extends work on the performance of values in alternative organizational settings. We focus on how norms, discourses and principles, such as alternative currencies and barter trade schemes, materialize in everyday practice in grassroots exchange networks (GENs). GENs form part of what are broadly described as 'diverse economies', characterizing exchange arrangements and forms of production that differ from the dominant capitalist economy (see Gritzas \& Kavoulakos, 2016). These aim to bring about social change (Gibson-Graham, 2003, 2008) through their diverse actors' engagement in shaping and (re)producing alternative economic futures (Lee, 2006, 2013). We combine economic geographers' materialist notion of value (Lee, 2006; Healy, 2009) with discursive poststructuralist analyses of normative values through the lens of performativity (Gibson-Graham, 2006, 2008, inspired by Judith Butler's work, see 1990, 1993) to theorize from our empirical data. This framework allows us to consider the implications of values performance in the context of GENs, and specifically to examine their effects on organizing alternatives.

Our contribution to organization studies is twofold. First, we examine the concept of 'values practices' (following Gehman et al., 2013) enacted by GENs during times of crisis. In doing so, we extend the performative understanding of values as situated in networks of practices by considering the intersections between material and discursive, as well as affective and relational, dynamics involved in the co-production of values. As our research shows, these specifically involve: (i) mobilizing values to reconfigure ideas of economic 
value; (ii) redefining social relations through new forms of organizing; and (iii) rethinking human values to enable sustainable living. Second, we propose that alternative exchanges are enacted through collectively-performed systems of values originating in macro-level, anticapitalist discourses, and that it is these collective performances of values at the micro(individual) and/or meso- (organizational) levels that eventually become significant drivers in the creation of alternative, post-capitalist futures. ${ }^{1}$ We therefore consider values practices as a political means of prefiguring different arrangements for social exchange and non-hegemonic governance structures.

The remainder of this article is organized as follows: The next section discusses community organizing in relation to the emergence of diverse economic exchange schemes, viewing them as both political and collectively co-constructed entities. In doing so, we stress the role of grassroots exchange schemes and values practices, using a performativity framework that attends to the performance of practices through which such values are enacted. We then present the methods and findings of our study of four GEN schemes in which such practices occurred. Abductive logic (Wodak, 2004; Alvesson \& Sköldberg, 2009) drives this analysis, centred around how values systems influence social transformations when these are jointly performed. We conclude by suggesting a need for future research on the collective performance of values and their role in the context of organizing alternatives.

\section{Grassroots Exchange Networks and the Collective Performance of Values Practices}

The 2008 GFC increased the importance and visibility of diverse modes of community organizing and solidarity economy initiatives. In response to the severe consequences of the resulting cuts in public spending, austerity and unemployment in many Eurozone countries and elsewhere, debates on alternative exchange schemes (Blanc, 2011; Gregory, 2009; North, 2007; Sahakian, 2014) gained momentum. These initiatives refocused researchers' attention 
on the need for a value-driven movement that might reconfigure power relations in ways conducive to the emergence of alternative organizing forms (Carroll, 2010; Jackson, 2011; Hillenkamp, Lapeyre, \& Lemaitre, 2013; Chen et al., 2013). While the concept of value and the redefinition of values are central to the establishment of such initiatives, it is less clear how these values come into being, how they are practised, and how their performance may lead to different organizing forms, alternative governance systems and/or non-hegemonic power structures.

Extant organization studies literature stresses the importance of values to organizational outcomes (Amis, Slack, \& Hinnings, 2002; Bourne \& Jenkins, 2013; Kraatz, Ventresca, \& Deng, 2010), but this recognition remains largely implicit (for an exception, see Perkmann \& Spicer, 2014 on the role of values in the development of a grassroots media collective). To address this gap, we examine how collective values and collaborative co-production processes mediate the evolution of values in a rapidly-transforming socio-economic context. We draw our inspiration from Gehman et al.'s (2013, p. 104) performance of values practices, which 'are subject to ongoing rework over time'; values are not static properties, but rather dynamic and evolving processes constituted and re-constituted through their collective performance in everyday practice. While the authors stress the performative aspects of values practices, they do not address the political nature of such transformations as they ignore the central issue of power directing these performances. Yet power dynamics and assumptions underpinning such processes are not neutral, and have distributional and political consequences. For instance, practices and subjectivities emerging from the performance of values through a relational nexus of exchanges (sustained by discourses and affects) aim actively to construct a worldview (and a world) that inspires new political imaginations and reinforces our sense of agency (Burke \& Schear, 2014).

To develop our theorization, we draw on empirical evidence from Greece, which 
experienced a rapid growth in community grassroots networks, including various social and solidarity initiatives (Daskalaki \& Kokkinidis, 2017), following almost a decade of neoliberal restructuring, austerity and recession. We focus on GENs, which are intrinsically heterogeneous spaces of ethical negotiation and decision making, comprising multiple mechanisms of exchange, forms of labour, economic relations and ownership (Healy, 2009; see also Cohen, 2017; Meyer \& Hudon, 2017). GENs thus offer potentially revealing case studies of diverse mechanisms and transactions, while highlighting internal contradictions embedded in emergent individual and collective power relations (Lee, Leyshon, Aldridge, Tooke, Williams, \& Thrift, 2004). Specifically, we examine how GENs are instituted, and explore whether, through the collective redefinition of social values (Seyfang, 2000; North, 2007), they may co-constitute spaces of personal and social transformation. We briefly explain the notion of value, the theory of value and values (Lee, 2006), and how we connect these with the poststructuralist idea of performativity developed by Gibson-Graham (2008), before discussing our cases.

\section{Analytical Framework}

Our analytical framework centres on the interplay between value and values. It emerged during analysis of the empirical work as we sought to better understand what mobilizes distinct socio-economic actors to organize and institute GENs. We realized that we needed perspectives that captured the constitution of value(s) and their transformation through practice, since issues of valuation and normative values appear to be central to GENs' establishment and evolution. For this, we turned to alternative economic geographies that draw their key inspiration from Marxism, and to the post-structuralist theorization of performative practice inspired by Judith Butler's work.

Performativity approaches point out that the 'categories of social life [...] are not selfstanding, "natural" or to be taken as given, but are the result of endless performances by 
human [...] and by non-human entities and artifacts' (MacKenzie, 2004, p. 305; see also MacKenzie \& Milo, 2003). Inspired by Butler's $(1990,1993)$ ideas in their studies of diverse economies, post-structuralist economic geographers (Gibson-Graham 2006, 2008, 2013, 2014; Narotzky \& Besnier, 2014; Roelvink, Martin, \& Gibson-Graham, 2015) have turned to the power of discourse to explain that performativity is the key concept that holds together the idea of transformation of both social structures and subjectivities. Importantly, such notions of performativity take account of how performance of values depends and relies on subjective appropriation of discourse, and how this peforming process affects and alters subjectivities. Such contributions therefore also elucidate how power is relational and reproduced through everyday material practices and performances of values.

Moreover, the concept of performativity (or the consequences of the performance of norms, discourses and practices), understood as both enunciation and enactment, has been widely employed to analyze the impact of economics on social arrangements (Callon, 1998). ${ }^{2}$ Specifically, economic geographers necessarily stress the intersections between material and social relations and practices in the formation and definition of value (Gibson-Graham, 2006, 2008, 2013; Gibson-Graham \& Roelvink, 2009; Lee, 2006, 2010), but differ in their emphases and conclusions on the role of materiality. For example, Lee (2006) argues that, in order to facilitate social and material survival, 'circuits of value must sustain the delivery of such flows of value in appropriate quantities and distributions across space and time'. These are not isolated events; rather, they should be capable of 'reproduction both geographically and historically' (Lee, 2006, p. 417, emphasis added). For Lee, the values embedded in the regulation and direction of circuits of reproduction reflect a wide range of social objectives, and influence environmental, religious and cultural notions of social justice. Values are 'the forms of life, relations, things, thoughts and practices that are held dear and are considered to be inalienable' (Lee, 2006, p. 415). Lee's analysis contributes to a better understanding of the 
'relationships between the materially inescapable feature of economic activity - that of the consumption, production and circulation of value - and the diversity of values shaping such materialities' (Lee, 2006, p. 417). In this context, we cannot disregard the material reality shaped by capitalism and the state.

Thus, whereas Gibson-Graham's view focuses on 'possible' rather than 'probable' economic alternatives, Lee's view is that it is not enough to accept the unpredictability (or openness) of the outcomes of this political project. Capitalist social relations are diverse and contested; hence, 'the uneven but expansionary historical geographies of capitalism serve to open up diverse localities whilst, at the same time, tending to reduce them to singular measures of value' (Lee et al., 2004, p. 600). Therefore, dominant power relations and discourses sustain the reproduction of current material economic conditions and social relations (Lee, 2006; Gritzas \& Kavoulakos, 2016). At the same time, prevailing social relations temporarily shape economic imaginaries 'through representational discourse about material success or failure' (Gritzas \& Kavoulakos, 2016, p. 922).

Nevertheless, such discourses and representations are inherently unstable, and are therefore infinitely iterable and open to interventions. These frames operate in everyday life, from the micro level of social relations to the macro level of global political relations, all aiding the presentation of partial accounts of social phenomena (Butler, 2009) and allowing us to intervene performatively in the social processes, while also reflecting power relations that constrain the possibilities of alternative imagination (Gritzas \& Kavoulakos, 2016). Adding to this, Lee (2006, p. 420) notes: 'once particular social relations of value have begun to take place, those engaged in and benefiting from them have an interest in ensuring that they may be extended and sustained'. Change then becomes possible only through crises in prevailing social relations that disrupt circuits of value (Lee, 2013; see also Gritzas \& Kavoulakos, 2016). 
Acknowledging the complementary aspects of the aforementioned approaches allows us to appreciate, first, that even the dominant imaginaries are dynamic, as they are constantly being constructed through diverse and multiple day-to-day practices; and second, that the possibilities of alternatives - the imperatives of material success and power relations - affect both the scalability of alternatives and their transformative potential. We thus argue for a performative ontological project that stresses the discursive, social and material as well as affective and relational constitution of values. This is based on a recognition of value as constructed through the formative intersection of the practice of values in the context of social relations, and the reflexive, performative and regulatory practice of theories of value. We propose that values practices (both social and economic) remain in a state of becoming, but changes in the social capacity of groups to perform different values may foster new ways of relating, in both the economic and social spheres.

This approach, which centres on the values work of groups and collectivities, allows us to explore how grassroots mobilization may create such possibilities by encouraging, strengthening and proliferating diverse economy initiatives. Such framing brings us closer to understanding not only how values are performed, but also how they are contested and reconstituted collectively through a variety of relational exchanges involving discourses and affects. Studying these initiatives is, in this sense, also performative, in that it fosters and shapes our understanding of their potentialities within and beyond the current economic system.

\section{Methodology and Methods}

\section{Research context}

Following the GFC, the Greek economy experienced deeper and longer-lasting contraction than in the USA's Great Depression of the 1930s. For instance, by 2016, economic output 
had shrunk by 30 per cent. Over the last eight years, the country has consistently had the highest rates of youth unemployment in Europe (Trading Economics, 2017). ${ }^{3}$ Austerity and harsh neoliberal policies have deeply fractured the country's social fabric, but have also provided fertile ground for the strengthening and development of new grassroots community initiatives as alternatives to capitalist models of growth-based development. This study examines some such initiatives, focusing on parallel-currency and non-monetary exchange schemes (referred to here as GENs) established during this period. There are currently 97 such schemes in Greece, including 48 time banks and various parallel-currency schemes in which prices are freely set by scheme members (see also Garefi \& Kalemaki, 2013). ${ }^{4}$ However, several are still in a (re-)organization phase, and many time banks have been set up or promoted by local authorities, and hence cannot be considered to be grassroots community-driven schemes.

We report on four relatively well-established GENs that form part of a wider landscape of grassroots economic activities and spaces of solidarity currently unfolding in Greece: (1) a parallel-currency scheme in a big island community; (2) a countrywide, online goods exchange network; (3) an art currency scheme; and (4) an exchange network operating, like the online scheme, with no currency, with goods and services exchanged for free. We applied two selection criteria that reflected the project's scope. First, we excluded transactions involving Euros or any other official currency. This was because we wanted to focus solely on schemes and community actors that 'monetized' the value of their own production, based on their own values and valuation processes. Second, we excluded transactions based on friendship or family relations, as the focus was on modes of economic exchange that were not based on kinship, friendship or intimate affinity. Of course, in many cases, relatives and friends participated in the same scheme, and many friendships emerged within the schemes. These cases are representative of the solidarity schemes included in a larger ongoing research 
project.

\section{Empirical setting}

The first case, Ex-Net, was a parallel currency scheme established in 2011 in a large city on a Greek island. Transactions were performed through a virtual accounting unit, ' $U$ ', with members setting the prices of goods and services. The network had passed through various stages of growth and recent decline. The scheme was organized through an open general assembly and several open management-coordination groups. The second case, G-T network, covered the entire country through an online platform on which members offered goods and services for exchange. The network had several coordinators, and reached 2,500 registered users in 2013. The third case, A-Bank, was a self-organized art collective based in Athens aiming to explore the possibility of using art for economic exchanges. The participants designed and constructed currencies, which were unique, numbered and registered copies of artwork with various denominations of value. Forty registered artists and several other individuals participated in this online artistic community, exchanging goods and services in 'Art cash' currency. The fourth scheme, R-Exchange, was similar to G-T in operating with no currency (goods and services were exchanged for free), but was local (based on one Greek island), and in 2012 had around 100 registered members. Table 1 presents a summary of the characteristics of the four selected study sites.

[Insert Table 1 about here]

\section{Research design}

The study was based on an open-ended and inductive research design. Adopting a performative practice lens allowed us to consider how establishing intersubjective meaning in terms of values creation and reproduction is a continuous process rather than a one-off event. Ethnographic methodologies, requiring deep engagement with fieldwork over an extended period of time, are able to provide such insights. These allowed us to attend to the multiple 
subjectivities of actors, and to consider the fragmented field within which the schemes were operating, while remaining mindful of the risk of over-essentializing the alternatives, including social movements and NGOs (Fischer, 1997). The sample to which we had access was necessarily small owing to the nature of our chosen research approach (see below). Thus, while this study provides considerable depth of analysis regarding the potential impact of non-monetary exchange schemes, caution should be exercised in generalizing the results to all grassroots solidarity formations emerging in the context of the crisis in Greece or elsewhere.

\section{Data collection}

Our data collection methods comprised extended ethnography, including interviews with and observations of participants in the schemes, and documentary analysis of minutes of assembly meetings and online network materials. The ethnographic fieldwork permitted experientially-rooted insights into the nature of solidarity economy networks and emergent forms of organizing. Author 3 conducted the participant observations and was also a member of two of the four schemes (Ex-Net and G-T). She participated in bazaars and assembly meetings, interviewed the participants and kept an ethnographic field diary. Around 2,000 hours of participant observations were conducted over 30 months. This created a context of direct involvement in the activities studied, and also provided a longitudinal perspective on the evolution of processes and relationships within these schemes, and multiple opportunities to keep abreast of activities as they evolved. In addition to recording detailed observations in a field diary, Author 3 also wrote analytical notes reflecting on her experience.

Unstructured interviews lasting between 25 minutes and two hours were carried out with 13 individuals ( 10 women and three men) aged between 26 and 45. Most respondents held an undergraduate or postgraduate degree, and about a third had no personal income in the official currency. ${ }^{5}$ The interviewees included two founding members and two other members 
of Ex-Net and of G-T, and three founding members and one other member of A-Bank. We also conducted one interview with the founding member of R-Exchange. One-to-one interviews were conducted in Ex-Net and R-Exchange, and both individual and group interviews in the other schemes. The respondents offered their views on solidarity exchanges, and explained their reasons for joining, and their visions and future plans for the schemes. The founding member interviewees provided a global view of the schemes' activities and history, while other interviewees helped us to unearth any issues unmentioned by the founding members (e.g internal politics, power play and contradictions).

Finally, identity statements, online forum discussions and posters were collected as primary data to complement and triangulate the participative aspects of the research project. These were used to structure, clarify and expand our understanding and interpretations of the findings. For confidentiality reasons, and in consultation with members of the schemes, all quotations are completely disassociated from the informant to enhance anonymity. ${ }^{6}$

\section{Data analysis}

During our analysis, we focused on both diary notes (ethnographic fieldnotes) and unstructured interviews with the schemes' participants to unveil the underlying values, principles and norms guiding their interactions and mediating community relationships and actions. The research process evolved iteratively, moving between analyzing the empirical materials and developing a conceptual framework. The themes were developed inductively from the entire dataset, using iterative thematic analysis (Attride-Stirling, 2001) to identify key issues arising from the exploration of different notions of values emerging in everyday practices across the four sites. Three interwoven dimensions derived from Gehman et al.'s (2013) work guided our analysis of the empirical material: how discourses on values were reproduced and circulated across the schemes; the role of values in collective action; and the 
performance of values practices. This led to the identification of new themes as we moved back and forth between data and theory (Alvesson \& Sköldberg, 2009).

In the first stage of analysis, we organized the transcribed interviews and diary notes to allow patterns and common themes to emerge. We focused on how our research participants talked about their motivations for joining the GENs, and how they indicated and identified different values influencing their choices and elaborated on the negotiation of values practices within their networks. We then recorded the discourses emerging from the participants' narratives at the four study sites. Specifically, we identified discursive patterns (word choices, expressions) that enabled our research participants to articulate who they were, what they were doing and why (Butler, 1990, 1993), with reference to their activities, social identities and organizational practices, as well as revealing how values practices were being collectively performed in the schemes ('the structure has been instinctive', 'the experimental nature of economic activity', 'giving things for free', 'the transaction is the feast'). Drawing on these discursive patterns and our ethnographic observations, the focus was on how values were being performed in GENs' everyday practices (Gibson-Graham, 2003, 2006). Accordingly, we identified three performances of values practices: mobilization of values, re-articulation of social relations, and sustainable living. We argue that these foster the emergence and evolution of grassroots initiatives with the potential to institute valuesdriven, post-capitalist organizational forms (see Figure 1).

[Insert Figure 1 about here]

\section{Findings: Toward a Value-Based Framework for Organizing Alternatives}

Our analysis revealed commonalities across the four cases, forming the key themes presented below; however, there were also substantive differences in the material dimensions of the alternative value systems deployed, which were prominent in the case of A-Bank. A-cash, its 
'alternative currency', was accompanied by a notice of guarantee because A-cash, as an artistic artefact, had material-artistic value as well as exchange value. This contrasted with G$\mathrm{T}$ and R-Exchange, whose activities were based on barter rather than parallel currencies, and with Ex-Net, whose parallel currency had no material value.

G-T had 918 registered online users in 2010, and its membership fluctuated significantly over time. The active members of the network were located largely in the two main Greek cities of Athens and Thessaloniki, where social events such as craft workshops and creators' bazaars were also organized. Despite high levels of online membership, reaching 2,500 users in 2013, levels of activity in G-T confirm other studies' findings of variations in levels of participation among registered members (e.g. Schneider, 1996). Research shows that, similarly to the offline world, democratic participation in online communities is constrained and enabling (Albrecht, 2006). ${ }^{7}$

In the following analysis, we focus on commonalities across the four schemes, particularly in relation to the mobilization of values, the re-articulation of social relations, and sustainable living (or what participants described as 'restoring humane values'). We show how these three collective performances were both constituted through and constitutive of alternative organizing. While we use these findings to theorize the performance of values in GENs, these are not distinct and separate, but interrelated values practices that affect both the emergence of GENs and their potential to produce alternative modes of organizing.

\section{Mobilization of values: The value of value(s) and the value of 'the priceless'}

Setting new rules for transactions and deciding the value of things were new experiences for the scheme members. This was reflected in the evolution of decisions and rules, as well as individuals' desire to avoid relying solely on monetary exchange systems: 
I need to offer, to create and to feel useful... Through my participation, I improve myself by observing how the team operates and by learning new things about value [...]. I try to become independent from money as much as possible (Ex-Net).

Before joining the schemes, most participants were unfamiliar with setting and evaluating value; that is, how 'value is put upon things, processes, and even human beings, under the social conditions prevailing within a dominantly capitalist mode of production' (Harvey, 1982, p. 38). According to Lee (2006), value is valued through social practice, and is geographically and historically variable. In the schemes we studied, people came together under conditions of acute crisis, where dominant economic models of exchange had reached their limits and the values underpinning them were failing. Participants instituted various mechanisms to regulate and evaluate value (for example, exchange without rates, free exchange, and exchange without time limits for reciprocation, as in free bazaars) as alternatives to those predicated on conventional monetary systems. For example, valuation mechanisms included a multiplicity of transaction practices for a single item (such as exchanges of traditional seeds) and setting alternative measures of value/equivalence (for instance in the case of A-Bank). Symbolic and non-monetary values were also instituted in various forms of co-production, using knowledge bases, expertise or time as currencies (see Glynos \& Speed, 2013; Bovaird, 2007). In the following vignette from our field diary, we reflect on how the networks practised regulation and evaluation of value:

In some cases, people seemed unsure about the price of their products during these transactions. It was also obvious that they were experimenting with prices, particularly during the first months. The issue of quantity and measures was particularly relevant when it came to food, for example: when it was their own produce, quantities were calculated by approximation, with most transactions being of generous measure. Second-hand goods and services were also exchanged, and these were more consistently available to customers than non-industrial goods produced by network members, such as agricultural products (Ethnographic vignette, Author 3).

Collective performances of value seemed to permit scheme participants to prioritize their own 'valuables', allowing them to decide for which transactions and under which rules members could join the scheme. One member of A-Bank explained: 
We aim to reveal the illusion of the value of money, to question the established value of money in social life and practise an alternative route, showing that our own currencies, which are art works of independent creators, can institute a new value system ... this can be achieved to the extent that art, the creator and her/his labour have an important place in the social and economic life of people (A-Bank).

Revealing 'the illusion of money' not only involved setting new rules for transactions, such as non-monetary transactions and new currencies, but also mobilizing values that members perceived as having been lost under the current monetary system:

Great values are being lost because of the current economic system; what we have achieved is that knowledge of other valuation systems can now be maintained and shared widely. For example, the idea of renewable is an ancient value [...]. Similarly, in the schemes nowadays, we talk about 'Banks of Services Exchange' or 'Volunteer Exchange' in an attempt to re-establish lost social webs (Ex-Net).

'Free bazaars' were also examples of schemes' attempts to restore what their members perceived as lost values. For example, participants recognized that 'there are items that are outside transaction zones', and commented frequently on 'the value of the priceless'; that is, 'the value of things that members give away for free' (Ex-Net). Free bazaars were organized regularly by participants, allowing them to exchange ideas, discursively re-construct prior values and collectively perform new modes of socio-economic activity. Author 3 participated in 22 bazaars organized by Ex-Net, all of which were well-attended. Also, as membership of the schemes grew significantly, more members began to participate in activities, shaping their roles and practices. In doing so, the participants disrupted established notions of value and collectively developed valuation practices that prioritized non-capitalist values, such as sharing, solidarity and caring for less privileged others. The following fieldnote explains how these non-capitalist values (in this case, the 'value of the priceless' - giving things for free) were performed when new members brought new demands, particularly in relation to the supply of free goods and services in the G-T network:

The G-T network, similarly to others, organizes free workshops and free-exchange bazaars, where people can exhibit and give for free items that they have created with materials they have acquired from other network members. Other GENs, for example the Athens Time Bank, organize free workshops where members (and non-members) 
can learn new skills. These free bazaars respond to changes in demand, particularly for free goods and services, triggered by the acute financial crisis. Schemes had to adapt to this climate by modifying their practices to include more free items or extending their activities to cover the needs of those who could not donate anything or otherwise participate in the exchange (Ethnographic vignette, Author 3).

Thus, mobilization of these 'lost values', including solidarity with those who could not make ends meet, triggered a change in members' personal values. More importantly, we found that collective performances of these values posed challenges not only to the very foundation of their espoused values, but also to how members related to each other when trying to institute alternatives in practice. This 'sociality of economic activity and the socially reproductive imperative of value creation' (Lee, 2006, p. 416) was apparent when participants engaged in problem resolution:

The greatest difficulty is always social relationships, but exactly when there is friction, the angles are rubbed... it is through problem solving that we create common perceptions and common values, overcoming differences and diverging viewpoints (Ex-Net).

While GENs' value practices remained contested, the participants' social capacity to perform different values fostered new ways of relating, both economically and socially, thus demonstrating the intertwining of the symbolic and material in the constitution of new forms of organizing exchange. Echoing Lee's (2006) perspective, which bridges material features of economic activity and the diversity of values shaping such materialities, we observed that there was 'nothing predetermined about the emergence of particular forms of social relations of value that developed' (Gritzas \& Kavoulakos, 2016). Instead, schemes' social relations of value remained diverse and dynamic (for example, more 'free-for-all' bazaars were organized as more people needed free products or services), and their form depended partially on the imperatives of what Lee (2006) calls 'life-sustaining' value, i.e., the means for societal reproduction that contribute to the sustenance of economic activity.

Nevertheless, values practices were contested and negotiated as members attempted to decide how to establish exchanges that departed from capitalist modes of transaction, and to 
mobilize their collective values. One participant explained: 'Embedding these values was tricky, and sometimes the practice of these values, unfortunately, remained unchallenged by group members' (R-Exchange). Learning the 'value of values' required members to engage in constant negotiation and dialogue with others in attempting to construct community responses to economic crisis. Crucially, as the following vignette from our field diary illustrates, these emerging and evolving values seemed to highlight a personal transformation for members who were trying to devise new practices of collective action:

The recently-established schemes often refer to the economic dimension of their activity, like how the economic system works, how the material economy is affected by its financialization; and they use the term 'crisis' not as an explanation for the existence and development of their schemes, but as a backdrop to discussing the motives and values of the schemes and their members. Thereby, the 'crisis' becomes just an event, not 'the' argument, nor the main reason for the activity. The 'crisis' is sufficient to explain the change in people's views about the economy and their own economic activity, but it seems also to affect members' willingness to start a discussion, search for and disperse new ideas, experiment with the economy, and undertake collective action to find or try possible solutions (Ethnographic vignette, Author 3).

A founding member of R-Exchange also discussed members' willingness to engage with new ideas and experiment with alternative economic arrangements when referring to how participants started to 'nurture the possibilities of diverse economies' (Ethnographic fieldnotes) and organize around shared values. Another participant commented on how these shared values were mobilized and gradually became integrated into the networks' practices:

We continuously adapt and the scheme's values constantly evolve... in a group of people where everyone has freedom of speech and freedom of opinion, there is space for reflection ... yet, people need time to get to know each other and create trusting relationships ... they need to integrate, become part of an economy without money. This requires a change of mentality, requires the cultivation of different values such as fairness (Ex-Net).

Thus, it is important to study the symbolic discursive underpinnings and 'the relationships between the materially inescapable feature of economic activity - that of the consumption, production and circulation of value - and the diversity of values shaping such materialities' (Lee, 2006, p. 417), to better understand how they both shape and are shaped by 
performances and shifts in values. In other words, the redefined system of values produced different material realities which were changing in practice as they were performed. Moreover, we realized that it was equally important to consider the affective relational ties that enabled such performances of values, including trust building (author/s), reflexivity, and reconsiderations of the relationship between self and community. As discussed in more detail below, GENs' organizational practices, such as general assemblies, invited members to participate in collective valuation processes, to decide what was 'of value' and reflect on the values mobilized in the process. Yet mobilizing values and integrating them into the networks' practices often involved dealing with social structures (such as patriarchy) that counteracted the schemes' commitment to horizontalism, equality and democratic participation, and instead maintained capitalist structures and values. To this issue we now turn.

\section{Organizing GENs: Re-articulation of social relations}

All schemes' identity statements stressed the values of egalitarianism and democratic participation, supported through the institution of horizontal, non-hierarchical structures. As one member stated, 'structure has been instinctive' (Ex-Net). Aiming to avoid traditional organizational arrangements with autocratic leaders (Bray, Campbell, \& Grant, 1974), 'any decisions made, are made as a group' (A-Bank). Open general assemblies, a practice in line with non-hierarchical organizing, nurtured deliberation under conditions of collective action (see Mouffe, 2000), enabled autonomous organizing structures and perpetuated the groups' commitment to alternative valuation systems:

The decisions were made in an open General Assembly, horizontally. There was also an administrative committee (that would rotate every three to four months), which was responsible for implementing the decisions of the General Assembly; some decision making was taking place there, nevertheless, for simple, practical things (RExchange). 
A few incidents required extensive interactions among members, and in most cases, the schemes' members reached agreement through consensual decision-making processes (see Della Porta, 2009): 'Any disagreements would be raised and openly discussed in the general assembly along with other agenda items' (Ethnographic fieldnotes). The networks' small scale and non-hierarchical, horizontal organization permitted transparency in negotiating differences and making decisions. However, it sometimes took weeks or months for members to reach agreement or turn decisions into actions. As noted in our fieldnotes, 'when the initiatives explored issues of valuation and pricing, we noted that any disagreements or disparities quickly became apparent and would rarely be left unnoticed or not dealt with'. The following reflective statement by a member reveals the daily negotiation of power and the contested social relations that might develop when trying to collectively decide "whose alternative values are being mobilized' (see also Seyfang \& Smith, 2007, p. 599):

The disagreements usually had to do with decisions that had a political and/or politico-ethical dimension: for example, with what other schemes shall we try to build alliances; should we accept sponsors for our events and cooperate with the municipality; what is our approach (theory and practice) towards solidarity and altruism; do we take a (political) stand towards a political incident? ... What caused most conflicts was the enactment of decisions in terms of how passive or active people were in the group (R-Exchange).

Supporting earlier studies of diverse economies (Gritzas \& Kavoulakos, 2016), we noted that power relations between core group members and newcomers or other network members could lead to contentious relationships and, at times, a gradual loss of community feeling. Relationships required time and constant renegotiation of values, but this posed a challenge, as time spent on performing various tasks became a proxy for currency denoting value in alternative exchange schemes because the core group members usually devoted significant amounts of voluntary time, and might therefore be unwilling to compromise (Gritzas \& Kavoulakos, 2016). One member described how some members of the group were consistently more active, both in sustaining group activities and in implementing the general 
assembly's decisions:

There was no particular process established in the schemes to resolve disagreements... What happened frequently was that the majority of the people would either not take the initiative to do the tasks [decided by the general assembly], or took the initiative but eventually wouldn't do the tasks. So what was happening, although rotation had been decided, most of the time it was the same people (the great majority women) who were involved in the implementation phase (R-Exchange).

Hence, debates during meetings were always emotionally charged, unveiling potential power imbalances constantly negotiated as part of the organizing process. Nevertheless, preexisting power relations in society (relating to gender, class, ethnicity, etc.) were often reproduced (see also author/s), despite most, if not all, members' self-proclaimed commitment to egalitarian and non-hierarchical values. More particularly, we sometimes witnessed the reproduction of gendered social expectations in relation to role and task responsibilities. Social hierarchies, particularly those defined by gender, were very difficult to address, especially since some scheme participants had very limited experience of being members of diverse and heterogeneous initiatives. Feminist analysis has drawn attention to:

...the tacit assumptions that the default activist was male (and indeed white, ablebodied and heterosexual); the tendency to consider gender as at best an add-on variable rather than a constitutive feature of social movements; a disregard for the role of embodiment, affect and emotion in the study of social movements and political mobilization (Dean \& Aune, 2015, p. 376).

A founding member of R-Exchange explained:

Men were more outspoken in the assemblies, and in some cases this was perceived as an aggressive behaviour, because it made it difficult for women or more quiet personalities to claim time and space in the assembly. Nevertheless, this attitude was challenged by women, and some men, and in most cases this challenge was very effective (R-Exchange).

Depending on both the structure of the scheme and members' collective decisions on whether or not to address an existing imbalance of power, conflicts were exacerbated or resolved through less formal decision-making processes and through emerging social relationships. Also, quoting from our ethnographic notes: 
We gladly noted a strong presence of women across all schemes, and active participation in both general assembly meetings and social events. To this contributed the fact that most schemes organized educational activities for children and ensured that specialist teachers and/or carers were available when members needed to participate in schemes' activities, such as assemblies, co-ordination meetings or solidarity events.

Nevertheless, when it came to decision-making processes, we noted that women less frequently found or were given sufficient space to develop their arguments, and sometimes resorted to discussions outside formal settings. Reflecting on this, women explained how they found ways to create solidarity relations with other members of the community (outside the schemes) and occasionally managed to influence the process through which decisions were implemented. One way was to re-contextualize individual differences and to reframe and transform collective practices by forming relational ties or 'affective exchanges' (Biggart \& Delbridge, 2004) with other scheme members:

Various conflicts were bridged through forming relational ties with other (scheme) members. However, this was done informally [...]. Of course, the more we knew each other, the easier the relationships and the communication. Personally, I would struggle on whether I should give priority to outputs (getting things done) or relationships, and how to balance the two (R-Exchange).

Thus, conflicts, and the processes through which the schemes' participants tried to resolve them, sometimes assisted efforts to avoid centralization and top-down control of the exchange process, but might also create factions that threatened scheme cohesion:

Having sub-groups of 2-3 people talking to each other informally (outside formal democratic structures) creates many problems and difficult dynamics. People choose sides and then things slowly fall apart. Yet, in cases when bridging the gap between the individual and the collective was possible, then real change in attitudes and behaviours occurred (R-Exchange).

Although horizontal decision-making processes were practised and encouraged across some networks, participants had to mediate and negotiate conflicts emanating from diverse performances of values. For this 'bridging' (of the individual and the collective) to occur, established spaces outside the general assembly were identified by members as essential: 
In my opinion, we need a different kind of assembly to discuss disagreements. You cannot discuss and resolve all practical issues and also deal with the emotional aspects, the relational, both in the same space (R-Exchange).

Also, confirming earlier findings, our study suggests that for some grassroots members, formal structures (such as the general assembly) were 'clearly not integrated into the group and remain inaccessible' to some members (Beeman, Guberman, Lamoureux, Fournier, \& Gervais, 2009, p. 880). This was partly because voluntary participation meant that relatively few members took part in the general assembly's decision-making process. To foster other spaces where affective bonds could be built, events such as open meetings, fairs, bazaars, seminars and workshops were frequently organized. As one founding member of Ex-Net described:

We saw that friendships were cultivated, for example, in spaces where we could release our creativity; fairs, workshops where people started working together, making things out of nothing (Ex-Net).

Participation in these events enabled members and non-members to exchange ideas, discursively re-construct prior values and collectively re-articulate social and economic relations, which often involved affective exchanges as participants expressed their attachment to the schemes' values. Thus, members did not focus solely on monetary or non-monetary value and how this was co-produced, but also highlighted that the schemes' shared values instigated new forms of social interaction and possibilities for personal and social transformation. An Ex-Net participant explained why he enjoyed being part of the scheme: 'I enjoy the collegiality and solidarity we have at the group, because I believe that we all together can do things that one person alone cannot do.' A member of A-Bank also commented on the social aspects of the schemes and the possibilities enacted:

I want to think about the scheme as a social space. I think that there are multiple dimensions in what we are doing here that we do not even imagine ... we have managed to establish a shared vision here and this can be the start of an alternative way of thinking about our community and about society as a whole (A-Bank).

Thus, conceptualizing the networks as social spaces enabled members to re-constitute 
them as fields in which they could explore solutions and forge solidarity relationships with other networks and grassroots initiatives.

\section{Sustainable living: Restoring 'humane values'}

Participating in alternative social formations, such as these community-driven schemes, became a transformative psychological and sociological experience:

There is faith that there are other moral values apart from money... we believe that the relations of people should be facilitated in the logic of transactions, not only by means of money, the known money ... it is related to an ethical way of life [...] in the sense that you go for a different logic that emphasizes humane values (G-T).

A member explained how inspiring it was to externalize these 'humane values' that everyone felt were part of their struggle for an alternative future:

I volunteered to take on the task to write up our identity statement [...]. When I read that statement back, we all went into a state of awe and silence (I didn't expect that the particular reading would have that effect). We had a shared moment of 'wow, this is who we are (want to be) and what we (want to) represent really?! Amazing!'. It was a very inspiring moment that it was apparent made us feel very united, that very moment (R-Exchange).

Restoring and practising 'humane values' also included respect for nature and the environment. Participants stated that, through their participation in GENs, they had learned to put values such as sustainability, ethics and the environment above profit. This indicates a movement away from a linear and sequential approach to value creation, toward more complex and dynamic exchange systems of actors (i.e. service ecosystems including nurture, regeneration and sustenance of all life), centred around value creation practices guided by norms, meanings and new organizing properties. For scheme members, sustainable living was clearly different from the conventional sustainability discourse that struggles to reconcile the goal of economic growth with social equity and environmental limits (Sahakian, 2014):

We devoted quite some time and effort to put together collectively our identity statement (vision and aims) that talked about the principle of sustainability in the sense of environmental sustainability (degrowth and social ecology principles). Our views around sustainability, environment and ethics were communicated and 
represented in our external actions and relationships. For example, when we would talk with potential or existing members of the exchange network (that were not participating in the group's internal processes), or when we would run events, talks etc., we would also refer to our identity statement (R-Exchange).

Furthermore, participants emphasized that the quest for a fulfilling life should focus on the need to change how humans relate to each other. As one participant stated, G-T tried to embed the practice of 'a good and ethical life for all'. At Ex-Net, participants also stressed the importance of 'mutual respect' and 'equality':

If we recognize human rights, the equality of humans, that each one can offer and enjoy the best possible on this earth within a perception of equality, if we do not have this, even these spaces of alternative exchange can become spaces of exploitation... if the agenda of human rights is not integrated [into the network], which is for tall people, for short people, for green, red, yellow people, a component of mutual respect, that I offer my services not only, for example, to tall people, nor ask services from tall people only, for me it is not worth being in this space (Ex-Net).

This is in line with a poststructuralist performative interpretation that sees values as being produced in the space where one relates to others (author/s). Sustainable living therefore requires happiness to be attained by living ethically, according to overarching moral principles on how we ought to treat others. For many participants, this implied a shift toward the economy of care and personal responsibility (see Williams, 2011). Another member of GT shared the following experience:

We live in times of economic crisis and we don't have the luxury of consumption that we had before. With consumption, we were getting some false joy; we went out, we did our shopping, etc. Personally, as a teacher, I have been preoccupied with environmental education for 25 years now; I am very interested in environmental sustainability and what people call recycling or reuse. This scheme is helping people to think in different ways, to say 'better to give it there, where people will give it a second chance, they will make something out of it, they will not throw it away'. This network questions this ingrained need for consumption and tries to make people think more about sustainable forms of living (G-T).

Overall, the relationships fostered by the schemes can be conceptualized as a form of social capital, resonating with discourses of responsibility and active citizenship (Westheimer \& Kahne, 2004). Such discourses 'include imaginaries - representations of how things might or could or should be' (Chiapello \& Fairclough, 2002, p. 195) that are enacted as actual 
practices: imagined activities, subjectivities or social relations become real through materializations of alternative discourses and practices. The GENs appeared to be striving to introduce fundamental changes to how community life was performed. As our analysis reveals, these performances included: first, mobilizing values and appreciating the value of values; second, espousing organizing principles that fostered the re-articulation of social relations; and finally, restoring humane values and establishing sustainable living.

\section{Discussion}

The GFC provided a context in which to explore the organizing potential of diverse economy initiatives in non-institutionalized, discontinuous, ambiguous and novel fields. To address this, we focused on the very moments in which discourses, texts and events were produced and came to shape GENs' values practices. The central role of values in underpinning organizational performance (Jurkiewicz \& Giacalone, 2004), culture (Cameron \& Quinn, 2011) and alternative organizing (Diani, 2013) has previously been acknowledged but remains poorly conceptualized. However, one recent study confirms our findings that GENs respond to and mobilize the values of the citizens involved, that specific values are held by people participating in societal experiments, and that values are mobilized and performed within such schemes on a collective scale (see Martin \& Upham, 2016). Members' desire to improve the living conditions of those with 'limited economic means' causes them to coalesce and intertwine in networked ways to promote alternative values production schemes.

Following this, we argue that value runs on a continuum between belief and action/nonaction ('belief' about a thing being the most valuable, and 'action' to protect what is considered to be most valuable) that is formed and continuously renegotiated by communities themselves (Graeber, 2006). In contrast to previous suggestions that participants often see 'values practices as ends in themselves and thus, analytically distinct from organizational 
practices' (Gehman et al., 2013, p. 84), based on evidence across the four cases, we suggest that joint performances of value are what drive communities to self-organize and constitute new social and economic relations. The poststructuralist performative approach informing our analysis suggests that such transformative potential may emerge from the collective performance of values practices. That is, the new social, ecological, cultural and financial landscapes that GENs assemble entail collectivist, participatory struggles that potentially bring about new social, cultural, and economic realities (see also Daskalaki, Hjorth, \& Mair, 2015). Such initiatives therefore become prefigurative, in the sense that they attempt 'to bring new forms of social relationships into being' (Parker, Cheney, Fournier, \& Land, 2014, p. 628; see also Boggs, 1977; Graeber, 2002).

We identify three distinct values practices that materialize out of situated and emergent performances, namely mobilization of values, re-articulation of social relations, and sustainable living. Supporting the work of other critical scholars who stress the need to understand and debate the values that 'tie together' alternative organizational forms (Parker et al., 2014, p. 625), we propose that these forms represent a diverse set of socio-material practices that reflect relationally-constructed understandings, constantly negotiated through direct democratic processes and horizontal, non-hierarchical organizational arrangements. Such post-capitalist arrangements appear to characterize GENs' efforts to escape the logic of relentless growth (Fournier, 2008), take back the economy (Gibson-Graham, Cameron, \& Healy, 2013) and 'operate as immanent critiques of existing forms of work organization' (Shukaitis, 2010, p. 63).

Accordingly, we argue that GENs seek to transform socio-economic exchanges by collectively mobilizing and restoring values and organizing principles that challenge dominant relations of production and consumption. Thus, GENs offer alternatives, or the potential to organize alternatives, to the static element of bounded institutionalized practices 
that 'represent constraints on the options that individuals and collectives are likely to exercise' (Barley \& Tolbert, 1997, p. 94). If not in strictly technocratic terms, grassroots initiatives comprise the actual spaces in which challenges to the mainstream model of monetary exchange are practised, or at least explored. For instance, collective performances of values allow participants to prioritize values differently, and to decide when, whether and under what rules transactions will take place. In cooperating in these initiatives, communities regain some control over the organizational process, despite the problems of knowledge transfer and sharing, and direct access and participation. They learn to interpret the world in a manner that fundamentally re-configures how power operates (Graeber, 2001; Maeckelbergh, 2011). For instance, many participants explained how non-consumerist and collectivist values, along with a desire to improve their living conditions and create a better world, served as an impetus for action. Hence, the schemes' collective purpose and orientation are clearly about the prefigurative politics involved in re-establishing values and community practices with a view to transforming social and economic relations.

This article contributes to several debates. First, it contributes to analysis of alternative economic practices (Gibson-Graham, 2003, 2008; Jonas, 2013; Lee, 2006, 2013) by connecting macro-political with meso-organizational and micro-individual relational levels. The connecting link is the notion of performativity, which explains how prefiguration of different values enables these alternatives to materialize, which are then reconfigured and reproduced through practices. While a multitude of practices and diverse forms of mixed community economies (Gibson-Graham, 2003, 2008; Healy, 2009; Jonas, 2013) have always existed in the hidden 'neverland' of alternative spaces (Gritzas \& Kavoulakos, 2016), their proliferation during the crisis poses important questions about their sustainability and potential to create alternative forms of organizing. Accordingly, central to our analysis is the performance of values practices pertaining to economic practices and arrangements that 
might offer ways to escape neoliberal capitalist determinism. This contribution also allows us to explore the potential for new forms of organizing centred on inclusive and non-hierarchical democratic governance that emerge from performing solidarity exchanges, and whether they apply market means for social ends (Doherty, Haugh, \& Lyon, 2014). According to Gehman et al. (2013), such new forms comprise loosely scripted but concerted collaborative problemsolving efforts and enable the re-definition of values practices through collective performances. Nevertheless, we demonstrate that values are reconfigured, redefined and reaffirmed through a process of relational performances of exchanges occurring at multiple levels, involving material artefacts, discourses and affects. In other words, while mobilization of values (in this case concerned with post-capitalist futures) is a necessary spark for action and the establishment of such initiatives, the re-production and sustenance of the value of the priceless, and non-hierarchical forms of sociality and humane living must be continuously performed and reiterated through practice. This also means that pre-existing power relationships (for instance, dominant gender structures) must be openly acknowledged and actively addressed. Hence, grassroots initiatives and schemes may become spaces where 'ethical choices for a post-capitalist future could be made, insofar as the existence of power relations and sustainability issues is acknowledged' (Gritzas \& Kavoulakos, 2016, p. 11).

Second, our study contributes to organizational scholarship on alternative forms of organizing as forces emerging outside and against institutions, directly contesting existing institutional arrangements for change or new path creation (Schneiberg \& Lounsbury, 2008). This responds to Den Hond, Bakker, and Smith's (2015) call to investigate the implications of social mobilization for the 'organization', and social movements' struggle to balance decided and emergent orders. We offer important insights into the role of new ideas and practices in this process. According to Parker et al. (2014), autonomy, solidarity and responsibility constitute general principles or values that link alternative organizational 
forms. Following this, we suggest that GENs are political, cultural and social phenomena that link to (potential) alternative organizational activities and represent a (potential) practised alternative to the financial instrumentalism characterizing capitalist modes of production. We argue that such bottom-up initiatives, emerging through community mobilization, are inherently political, subversive practices of resisting established patterns of organizing. We also demonstrate that people's values are central to this work of reconfiguring new ways of organizing, adding new evidence to organization studies in the context of GENs. Overall, we suggest that a grassroots context may become a fertile space for social change to occur, by identifying and mobilizing values collectively, and testing and practising new social relations and sustainable living. The importance and strength of such initiatives lies in their ability to prefigure things that do not yet exist, and hence to reimagine possible alternative futures (see Komporozos-Athanasiou \& Fotaki, 2015).

\section{Concluding remarks}

The GENs studied in this article appear to have been striving to introduce fundamental changes to how community life is performed, and to implement changes driven by values other than monetary concerns. We acknowledge that the potential for GENs to tackle social inequality has been challenged (Bowring, 1998; see also Sahakian, 2014); yet the search for alternative futures is not only constrained but also, as Böhm, Dinerstein, and Spicer (2010) point out, enabled by economic, political, social and cultural settings and situations. Our own position has been to investigate this potential without beautifying the struggles and antitheses that emerge in every social space, especially under harsh political and economic conditions. This has allowed us to argue that community mobilization is defined by an endeavour to promote values practices that prioritize ethical living during times of crisis. However, we are mindful that studies of solidarity economies have a tendency to romanticize achievements 
and simplify the limitations and contradictions. Hence, we should also stress the importance of exploring how communities constantly evolve and challenge capitalist relations through acting, experimenting and redefining their understanding of co-operation in contexts of ambiguity and flux, and how they re-organize their activities to overcome difficulties and transform dominant structures of social engagement and economic exchange.

Grassroots initiatives are continuously evolving and changing, owing not only to internal processes, but also to the broader landscape of potential alternatives currently unfolding in Greece and elsewhere. Consequently, we do not suggest that the values practices presented here can be generalized to other community initiatives, or even that those we describe are actually stable. We can only claim to have interpreted the initiatives' practices as these were performed at a given point in time when the research project was conducted. Future longitudinal work might address the sustainability of these initiatives, focusing specifically on the challenges they face when interacting with established, institutionalized exchanges and market-driven norms and values. More focused research is also needed to explore virtual spaces of collaboration and processes that support or endanger the transformative capacity of grassroots communities engaged in the co-production of different forms of exchange. Finally, the groups' small scale and horizontal management structure might create the much-needed transparency lacking in the mainstream economy. As their size increases, it remains to be seen how these mechanisms will develop, and how others will be instituted in attempts to protect and secure both transparency and potential for socially transformative engagement.

\section{References}

Albrecht, S. (2006). Whose voice is heard in online deliberation? A study of participation and representation in political debates on the internet. Information, Community and Society, $9(1), 62-82$.

Alvesson, M., \& Sköldberg, K. (2009). Reflexive methodology. London, UK: Sage. 
Amin, A. (2009). Locating the social economy. In A. Amin (Ed.), The social economy: International perspectives on economic solidarity (pp. 3-22). London, UK: Zed Books.

Amis, J., Slack, T., \& Hinings, C. (2002). Values and organizational change. Journal of Applied Behavioral Science, 38(4), 436-465.

Arampatzi, A. (2016). The spatiality of counter-austerity politics in Athens, Greece: Emergent 'urban solidarity spaces'. Urban Studies, 54(9), 2155-2171.

Attride-Stirling, J. (2001). Thematic networks: An analytic tool for qualitative research. Qualitative Research, 1(3), 385-405.

Barley, S. R., \& Tolbert, P. S. (1997). Institutionalization and structuration: Studying the links between action and institution. Organization Studies, 18(1), 93-117.

Beeman, J., Guberman, N., Lamoureux, J., Fournier, D., \& Gervais, L. (2009). Beyond structures to democracy as culture. American Behavioral Scientist, 52(6), 867-884.

Biggart, N. W., \& Delbridge, R. (2004). Systems of exchange. Academy of Management Review, 29(1), 28-49.

Blanc, J. (2011). Classifying 'CCs': Community, complementary and local currencies. International Journal of Community Currency Research, 15, 4-10.

Boggs, C. (1977). Marxism, prefigurative communism, and the problem of workers' control. Radical America, 11(6), 12-24.

Böhm, S., Dinerstein, A. C., \& Spicer, A. (2010). (Im)possibilities of autonomy: Social movements in and beyond capital, the state and development. Social Movement Studies, 9(1), 17-32.

Bourne, H., \& Jenkins, M. (2013). Organizational values: A dynamic perspective. Organization Studies, 34(4), 495-514.

Bovaird, T. (2007). Beyond engagement and participation: Users and community coproduction of services. Public Administration Review, 67(5), 846-860.

Bowring, F. (1998). LETS: An eco-socialist initiative? New Left Review, 232, 91-111.

Bray, D. W., Campbell, R. J., \& Grant, D. L. (1974). Formative years in business: A longterm AT\&T study of managerial lives. New York, NY: Wiley.

Burke, B. J., \& Schear, B. (2014). Introduction: Engaged scholarship for non-capitalist political ecologies. Journal of Political Ecology, 21, 127-144.

Butler, J. (1990). Gender trouble: Feminism and the subversion of identity. London, UK: Routledge.

Butler, J. (1993). Bodies that matter: On the discursive limits of 'sex'. London, UK: Routledge. 
Callon, M., Ed. (1998). The laws of the markets. Oxford, UK: Blackwell.

Cameron, K. S., \& Quinn, R. E. (2011). Diagnosing and changing organizational culture: Based on the competing values framework. San Francisco, CA: John Wiley \& Sons.

Carroll, W. K. (2010). Crisis, movements, counter-hegemony: In search of the new. Interface, 2(2), 168-198.

Chatzidakis, A. (2013). Commodity fights in post-2008 Athens: Zapatistas coffee, Kropotkinian drinks and fascist rice. Ephemera: Theory \& Politics in Organization, 13(2), 459-468.

Chen, K. K., Lune, H., \& Queen, E. L. (2013). How values shape and are shaped by nonprofit and voluntary organizations: The current state of the field. Nonprofit and Voluntary Sector Quarterly, 42(5), 856-885.

Cheney, G., Cruz, I., Peredo, A. M., \& Nazareno E. (2014). Worker cooperatives as an organizational alternative: Challenges, achievements and promise in business governance and ownership. Organization, 21(5), 591-603.

Chiapello, E., \& Fairclough, N. (2002). Understanding the new management ideology: A transdisciplinary contribution from critical discourse theory and new sociology of capitalism. Discourse \& Society, 13(2), 185-208.

Cohen, B. (2017). The rise of alternative currencies in post-capitalism. Journal of Management Studies, 54(5), 739-746.

Coleman, S., \& Blumler, J. G. (2009). The Internet and democratic citizenship: Theory, practice and policy. Cambridge, UK: Cambridge University Press.

Daskalaki, M. (2017). Alternative organizing in times of crisis: Resistance assemblages and socio-spatial solidarity. European Urban and Regional Studies, 25(2), 155-170.

Daskalaki, M., Hjorth, D., \& Mair, J. (2015). Are entrepreneurship, communities, and social transformation related? Journal of Management Inquiry, 24(4), 419-423.

Daskalaki, M., \& Kokkinidis, G. (2017). Organizing solidarity initiatives: A socio-spatial conceptualization of resistance. Organization Studies, 38(9), 1303-1325.

De Bakker, F. G. A., Den Hond, F., King, B., \& Weber, K. (2013). Social movements, civil society and corporations: Taking stock and looking ahead. Organization Studies, 34(5-6), $573-593$.

Dean, J., \& Aune, K. (2015). Feminism resurgent? Mapping contemporary feminist activisms in Europe. Social Movement Studies, 14(4), 375-395. 
Della Porta, D. (2009). Democracy and social movements. Oxford, UK: Blackwell Publishing Ltd.

Den Hond, F., De Bakker, F. G. A., \& Smith, N. (2015). Social movements and organizational analysis. In D. della Porta, \& M. Diani (Eds.), Handbook of social movements (pp. 291-305). Oxford, UK: Oxford University Press.

Diani, M. (2013). Networks and social movements. In D. A. Snow, D. della Porta, B. Klandermans, \& D. McAdam (Eds.), The Wiley-Blackwell encyclopaedia of social and political movements. Hoboken, NJ: John Wiley \& Sons. doi:10.1002/9780470674871.wbespm438

Dinerstein, A. C. (2007). Workers' factory takeovers and new state policies: Towards the 'institutionalization' of non-governmental public action in Argentina. Policy and Politics, 35(3), 529-550.

Doherty, B., Haugh, H., \& Lyon. F. (2014). Social enterprises as hybrid organizations: A review and research agenda. International Journal of Management Reviews, 16(4), 417436.

Fischer, W. F. (1997). Doing good? The politics and antipolitics of NGO practices. Annual Review of Anthropology, 26(1), 439-464.

Fournier, V. (2008). Escaping from the economy: The politics of degrowth. Journal of Sociology and Social Policy, 28(11-12), 528-545.

Garefi, I., \& Kalemaki, E. (2013). Informal citizen networks: The case of Greece. Report from 'The theoretical, empirical and policy foundations for building social innovation in Europe' (TEPSIE) project. DG Research, European Commission, Brussels, Belgium.

Gehman, J., Treviño, L., \& Garud, R. (2013). Values work: A process study of the emergence and performance of organizational values practices. Academy of Management Journal, $56(1), 84-112$.

Gibson-Graham, J. K. (2003). Enabling ethical economies: Cooperativism and class. Critical Sociology, 29(2), 123-161.

Gibson-Graham, J. K. (2006). A postcapitalist politics. Minneapolis, MN: University of Minnesota Press.

Gibson-Graham, J. K. (2008). Diverse economies: Performative practices for other worlds. Progress in Human Geography, 32(5), 613-632.

Gibson-Graham, J. K. (2014). Rethinking the economy with thick description and weak theory. Current Anthropology, 55(S9), S147-S153. 
Gibson-Graham, J. K., Cameron, J., \& Healy, S. (2013). Take back the economy: An ethical guide for transforming our communities. Minneapolis, MN: University of Minnesota Press.

Gibson-Graham, J. K., \& Roelvink, G. (2009). Social innovation for community economies. In D. MacCallum, F. Moulaert, J. Hillier, \& S. V. Haddock (Eds.), Social innovation and territorial development (pp. 25-37). Farnham, UK: Ashgate Publishing Ltd.

Glynos, J., \& Speed, E. (2012). Varieties of co-production in public services: Time banks in a UK health policy context. Critical Policy Studies, 6(4), 402-433.

Graeber, D. (2001). Toward an anthropological theory of value: The false coin of our own dreams. New York, NY: Palgrave Macmillan.

Graeber, D. (2002). A movement of movements: The new anarchists. New Left Review, 13, $61-73$.

Graeber, D. (2006). Turning modes of production inside out: Or, why capitalism is a transformation of slavery. Critique of Anthropology, 26(1), 61-85.

Gregory, L. (2009). Change takes time: Exploring structural and development issues of time banking. International Journal of Community Currency Research, 13, 19-32.

Gritzas, G., \& Kavoulakos, K. I. (2016). Diverse economies and alternative spaces: An overview of approaches and practices. European Urban and Regional Studies, 23(4), 917-934.

Harvey, D. (1982). Limits to capital. Oxford, UK: Basil Blackwell.

Healy, S. (2009). Economies, alternative. In Kitchin, R., \& Thrift, N. (Eds.), International encyclopaedia of human geography, Vol. 3 (pp. 338-344). Oxford, UK: Elsevier.

Hillenkamp, L., Lapeyre, F., \& Lemaitre, A., Eds. (2013) Securing livelihoods: Informal economy practices and institutions. Oxford, UK: Oxford University Press.

Jackson, T. (2011). Prosperity without growth: Economics for a finite planet. London, UK: Earthscan.

Jonas, A. E. (2013). Place and region III: Alternative regionalisms. Progress in Human Geography, 37(6), 822-828.

Jurkiewicz, C. L., \& Giacalone, R. A. (2004). A values framework for measuring the impact of workplace spirituality on organizational performance. Journal of Business Ethics, 49(2), 129-142.

Karyotis, T., \& Kioupiolis, A. (2015). Self-managing the commons in contemporary Greece: From agricultural co-operatives to an emerging solidarity economy. In I. Ness, \& D. Azzellini (Eds.), Ours to master and to own, Vol. 2. 
Komporozos-Athanasiou, A., \& Fotaki, M. (2015). A theory of imagination for organization studies using the work of Cornelius Castoriadis. Organization Studies, 36(3), 321-342.

Kraatz, M. S., Ventresca, M. J., \& Deng, L. (2010). Precarious values and mundane innovations: Enrollment management in American liberal arts colleges. Academy of Management Journal, 53(6), 1521-1545.

Lee, R. (2006). The ordinary economy: Tangled up in values and geography. Transactions of the Institute of British Geographers, 31(4), 413-432.

Lee, R. (2013). The possibilities of economic difference: Social relations of value, space and economic geographies. In H. M. Zademach, \& S. Hillebrand, Eds. (2014). Alternative economies and spaces: New perspectives for a sustainable economy (pp. 69-85). Bielefeld, Germany: Transcript Verlag.

Lee, R., Leyshon, A., Aldridge, T., Tooke, J., Williams, C., \& Thrift, N. (2004). Making geographies and histories? Constructing local circuits of value. Environment and Planning D: Society and Space, 22(4), 595-617.

MacKenzie, D. (2004). The big, bad wolf and the rational market: Portfolio insurance, the 1987 crash and the performativity of economics. Economy and Society, 33(3), 303-334.

MacKenzie, D., \& Milo, Y. (2003) Constructing a market, performing theory: The historical sociology of a financial derivatives exchange. American Journal of Sociology, 109(1), $107-145$.

Maeckelbergh, M. (2011). Doing is believing: Prefiguration as strategic practice in the alterglobalization movement. Social Movement Studies, 10(1), 1-20.

Markus, M. L. (2007). The governance of free/open source software projects: Monolithic, multidimensional, or configurational? Journal of Management \& Governance, 11(2), $151-163$.

Martin, C. J., \& Upham, P. (2016). Grassroots social innovation and the mobilisation of values in collaborative consumption: A conceptual model. Journal of Cleaner Production, 134, 204-213.

Meyer, C. R. C., \& Hudon, M. (2016). Money and the commons: Lessons from complementary currencies. Academy of Management Proceedings, 1, 14064.

Mouffe, C. (2000). Deliberative democracy or agonistic pluralism? Vienna, Austria: Institute for Advanced Studies.

Narotzky, S., \& Besnier, N. (2014). Crisis, value, and hope: Rethinking the economy. Current Anthropology, 55(S9), S4-S16. 
North, P. (2007). Money and liberation: The micropolitics of alternative currency movements. Minneapolis, MN: University of Minnesota Press.

O’Reilly J., Lain, D., Sheehan, M., Smale, B., \& Stuart, M. (2011). Managing uncertainty: The crisis, its consequences and the global workforce. Work, Employment \& Society, 25(4), 581-595.

Parker, M., Cheney, G., Fournier, V., \& Land, C., Eds. (2014). The companion to alternative organization. London, UK: Routledge.

Perkmann, M., \& Spicer, A. (2014). How emerging organizations take form: The role of imprinting and values in organizational bricolage. Organization Science, 25(6), 17851806.

Petropoulou, C. C. (2013). 'Alternative networks of collectivities' and 'solidarity-cooperative economy' in Greek cities: Exploring their theoretical origins. Journal of Regional \& Socio-Economic Issues, 3(2), 61-85.

Roelvink, G., Martin, K. S., \& Gibson-Graham, J. K., Eds. (2015). Making other worlds possible: Performing diverse economies Minneapolis, MN: University of Minnesota Press.

Sahakian, M. (2014). Complementary currencies: What opportunities for sustainable consumption in times of crisis and beyond? Sustainability: Science, Practice, \& Policy, 10(1), 4-13.

Schneiberg, M., \& Lounsbury, M. (2008). Social movements and institutional analysis. In R. Greenwood, C. Oliver, K. Sahlin-Andersson, \& R. Suddaby (Eds.), The Sage handbook of organizational institutionalism. London, UK: Sage.

Schneider, S. M. (1996). Creating a democratic public sphere through political discussion: A case study of abortion conversation on the Internet. Social Science Computer Review, 14(4), 373-393.

Seyfang, G. (2000). The Euro, the pound and the shell in our pockets: Rationales for complementary currencies in a global economy. New Political Economy, 5(2), 227-246.

Seyfang, G., \& Smith, A. (2007). Grassroots innovations for sustainable development: Towards a new research and policy agenda. Environmental Politics, 16(4), 584-603.

Shukaitis, S. (2010). Sisyphus and the labour of imagination: Autonomy, cultural production, and the antinomies of worker self-management. Affinities: A Journal of Radical Theory, Culture, and Action, 4, 57-82.

Trading Economics (2017). Greece: Unemployment rates. Trading Economics. Retrieved from: https://tradingeconomics.com/greece/unemployment-rate. 
Westheimer, J., \& Kahne, J. (2004) What kind of citizen? The politics of educating for democracy. American Educational Research Journal, 41(2), 237-269.

Williams, F. (2011). Towards a transnational analysis of the political economy of care. In R. Mahon, \& F. Robinson (Eds.), Feminist ethics and social policy: Towards a new global political economy of care (pp. 21-38). Vancouver, BC: UBC Press.

Wodak, R. (2004). Critical discourse analysis. In C. Seale, J. F. Gubrium, \& D. Silverman (Eds.), Qualitative research practice (pp. 197-213). London, UK: Sage.

\begin{abstract}
Notes
1 In the context of our work, 'alternatives' also encompass environmentally- and socially-aware arrangements that defy capitalist and patriarchal/racist exploitation.

2 For Callon, the discipline of economics is performative rather than descriptive since its pronouncements and statements may create and enact the world that they are meant to analyze.

3 This was caused largely by the exceptional disciplinary austerity policies enforced on consecutive Greek governments by a troika of lenders (the European Commission, the European Central Bank and the International Monetary Fund), resulting in loss of productive capacity, disinvestment, unprecedented unemployment, corrosion of employment conditions, rising inequalities and poverty. $4 \mathrm{http}: / /$ www.enallaktikos.gr/kg15el_topika-enallaktika-nomismata_t $40 . \mathrm{html}$.

5 The gender, income and education profiles of participants correspond with those of earlier studies of GENs in Greece (see, for example, Author/s, 2011).

6 To avoid identification of study participants, we do not use (pseudo-)names for any of the quotations shared in the results. Owing to the small scale of some of the initiatives and the tight ties within the solidarity economy, ascribing statements to specific individuals would compromise informants' anonymity.

7 Previous studies of e-democracy and governance suggest that online civic commons constitute a trusted public space in which the dispersed energies, self-articulations and aspirations of citizens can be rehearsed in public (see, for example, Coleman \& Blumler, 2009; Markus, 2007). Although, these debates are not discussed here, we consider it important for future studies to focus on how direct democratic processes are ensured in online communities of practice and affect the mobilization and collective performance of values practices in grassroots organizing contexts.
\end{abstract}


Table 1. The Case Studies

\begin{tabular}{|c|c|c|c|c|c|}
\hline Schemes & Location & Exchanges & Activities & Organization & Members \\
\hline Ex-Net & Greek Island & $\begin{array}{c}\text { 'U' (Alternative } \\
\text { currency) } \\
\text { Barter }\end{array}$ & $\begin{array}{l}\text { Goods } \\
\text { Services }\end{array}$ & $\begin{array}{c}\text { Assembly and open } \\
\text { management- } \\
\text { coordination groups } \\
\text { Open markets' } \\
\text { organization } \\
\text { Online platform \& } \\
\text { transaction system } \\
\text { Social benefit actions }\end{array}$ & 850 \\
\hline G-T & Country-wide & Barter & $\begin{array}{l}\text { Second-hand } \\
\text { products } \\
\text { Home-made } \\
\text { organic food } \\
\text { Raw materials } \\
\text { for crafting } \\
\text { Original } \\
\text { handicraft and } \\
\text { artwork }\end{array}$ & $\begin{array}{l}\text { Several coordinators } \\
\text { Open discussion } \\
\text { forums } \\
\text { Online transaction } \\
\text { system } \\
\text { Online bazaars }\end{array}$ & 2500 (registered users*) \\
\hline R-Exchange & Greek island & Free & $\begin{array}{l}\text { Second-hand } \\
\text { products } \\
\text { Home-made } \\
\text { organic food } \\
\text { Raw materials } \\
\text { for crafting } \\
\text { Original } \\
\text { handicraft and } \\
\text { artwork }\end{array}$ & $\begin{array}{l}\text { Several coordinators } \\
\text { Open discussion } \\
\text { forums } \\
\text { Online transaction } \\
\text { system } \\
\text { Online bazaars }\end{array}$ & 100 \\
\hline A-Bank & $\begin{array}{l}\text { Athens, } \\
\text { Greece }\end{array}$ & $\begin{array}{c}\text { Art Cash } \\
\text { (Alternative } \\
\text { Currency) } \\
\text { Artistic Artefacts }\end{array}$ & $\begin{array}{c}\text { Registered Art } \\
\text { Work } \\
\text { Artistic } \\
\text { Artefacts } \\
\text { Goods \& } \\
\text { Services }\end{array}$ & $\begin{array}{l}\text { Several coordinators } \\
\text { Open discussion } \\
\text { forums } \\
\text { Online transaction } \\
\text { system }\end{array}$ & $\begin{array}{c}40 \text { (Registered } \\
\text { artists**) }\end{array}$ \\
\hline
\end{tabular}

* The number of registered users who regularly participate in online exchanges and actively join the schemes bazaars and fairs is not available.

** This number idicates the number of artists who have joined the scheme. The number of ABank participants who perform economic exhanges with A-cash is not available. 


\section{Discursive construction of Grassroots Exchange Network}

- Collective valuation practices

- Exchanges 'outside transaction zones' and are considered 'priceless'

- There are things that

'members give for free'

- Lost values to be restored
- 'The structure has been instinctive'.

- 'Non-hierarchical organization'

- Constitute platforms for relational ties and

knowledge sharing.

- Experimental nature of economic activity.
- Explicit references to 'humane values'

- 'Protect the Earth'

- Sustainability, sustainable futures/sustainable lives

- Economy of love

- Embedding sustainable practices

\section{Collective Performances of Values Practices}

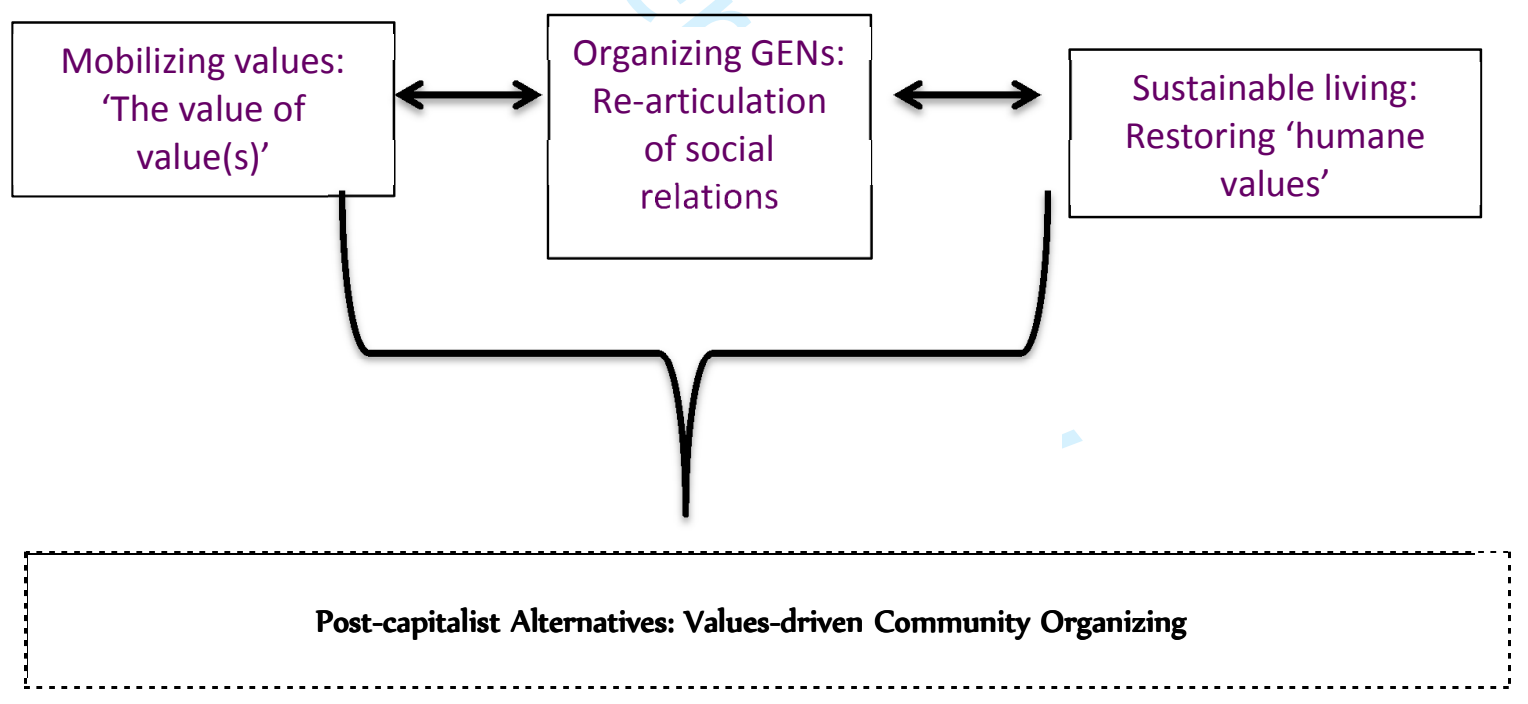

Figure 1. Emergent Themes: Performances of Values Practices 